\title{
Edukasi dan Sosialisasi Pencegahan Penyebaran Covid-19 dengan Cuci Tangan yang Baik dan Benar
}

\author{
Irfanita Nurhidayah ${ }^{1 *}$, Sri Novitayani ${ }^{2}$, Riski Amalia ${ }^{3}$, Najihah ${ }^{4}$ \\ 1,2,3 Fakultas Keperawatan, Universitas Syiah Kuala, Aceh \\ ${ }^{4}$ Jurusan Keperawatan, Universitas Borneo Tarakan
}

*Irfanita Nurhidayah

Email:

irfanita.nurhidayah@unsyiah.ac.id

\section{History Artikel}

Received : 13-07-2021

Accepted : 30-08-2021

Published : 31-08-2021

\begin{abstract}
Abstrak
Pandemi COVID-19 telah menyebar ke berbagai negara pada waktu yang berbeda, tergantung pada sistem politik, kesiapan layanan kesehatan, dan kondisi ekonomi. Pemerintah secara aktif merumuskan rencana untuk menghadapi virus pandemi global ini. Salah satu cara utama yang dapat dilakukan masyarakat untuk mengendalikan penyebaran COVID-19 adalah dengan mencuci tangan dengan benar dan benar. Mencuci tangan dengan sabun dapat mencegah penyebaran virus Covid-19. Tujuan dari pengabdian masyarakat ini adalah memberikan edukasi dan sosialisasi cuci tangan yang baik dan benar dalam rangka pencegahan Covid-19. Metode yang digunakan dalam melakukan kegiatan pengabdian ini adalah dengan memberikan pemahaman dan mempraktikkan langsung bagaimana cuci tangan yang baik dan benar melalui media leaflet dan praktik langsung kepada masyarakat. Hasil dari kegiatan edukasi dan sosialosasi cuci tangan yang baik dan benar ini terbukti dapat menambah pengetahuan masyarakat tentang pentingnya Pentingnya cuci tangan yang baik dan benar dalam rangka untuk mencegah Penyebaran Covid-19.
\end{abstract}

Kata Kunci: Edukasi, Sosialasi, Covid-19, Cuci Tangan

\begin{abstract}
The COVID-19 pandemic has spread to different countries at different times, depending on the political system, readiness of healthcare services, and economic conditions. The government is actively formulating plans to deal with this global pandemic virus. One of the main ways that people can do to control the spread of COVID-19 is to wash their hands properly and properly. Washing hands with soap can prevent the spread of the Covid-19 virus. The purpose of this community service is to provide education and good and correct hand washing in the context of preventing Covid-19. The method used in carrying out this service is to provide understanding and direct practice on how to wash hands properly and correctly through media leaflets and direct practice to the community. The results of good and correct hand washing education and outreach activities have proven to be able to increase public knowledge about the importance of good and correct hand washing in order to prevent the spread of Covid-19.
\end{abstract}

Keywords: Education, Socialization, Covid-19, Hand Washing 


\section{Pendahuluan}

Covid-19 adalah kelompok besar virus SARS dan MERS yang dapat menyebabkan penyakit mulai dari gejala ringan hingga berat. Covid-19 adalah virus dalam keluarga coronavirus yang dapat menginfeksi sistem pernapasan manusia dan hewan. Efek dari infeksi virus ini dapat berkisar dari ringan hingga berat, dan bahkan menyebabkan kematian (Badan Informasi Geospasial 2021). Virus ini pertama kali terdeteksi di Wuhan, Provinsi Hubei, China pada akhir tahun 2019 dan dengan cepat menyebar ke negara-negara Timur lainnya (misalnya Korea Selatan, Jepang, Iran) serta negara yang berada pada benua Amerika dan Eropa (Remuzzi and Remuzzi 2020). Data januari 2021 Covid-19 telah menginfeksi sebanyak 97.233.164 orang di seluruh dunia. Dari jumlah tersebut, 69.783.307 orang telah pulih dari infeksi. Pada saat yang sama, virus tersebut telah menyebabkan 2.080.402 kematian di seluruh dunia (WHO 2020b). Di Indonesia terdapat 1.066.313 kasus pada bulan januari dan Pasien meninggal sebanyak 29.728 orang (Satgas Penanganan COVID-19 2020).

Hampir seluruh dunia sekarang bekerja dari rumah untuk menghindari infeksi dari penyakit ini. Orang - orang semua umur bisa terinfeksi Covid-19. Langkah-langkah luas untuk meminimalkan penularan dari manusia ke manusia diperlukan untuk mengendalikan kejadian luar biasa saat ini. Saat ini upaya telah dilakukan, baik tindakan farmasi dan tindakan non-farmasi tersedia untuk melawan COVID-19. Meskipun tindakan farmasi adalah strategi yang paling efektif, namun, dibutuhkan banyak waktu untuk mengembangkan vaksin dan obat antivirus, sehingga mereka tidak dapat mengendalikan wabah yang disebabkan oleh virus baru patogen pada tahap awal. Dalam keadaan ini, tindakan non-farmasi seperti memakai wajah masker dan cuci tangan penting untuk mengurangi risiko dengan membangun penghalang untuk mengekang aerosol menyebarkan dan melindungi populasi yang rentan (Aiello et al. 2012; Aledort et al. 2007).

Direkomendasikan langkah-langkah untuk mencegah infeksi termasuk sering mencuci tangan. Munculnya COVID-19 semakin menegaskan pentingnya cuci tangan. Untuk mencegah penularan virus, Centers for Disease Control and Prevention (CDC) merekomendasikan untuk selalu mencuci tangan dengan sabun dan air mengalir. Menurut Pusat Pengendalian dan Pencegahan Penyakit AS, saat ini diyakini bahwa virus dapat menyebar melalui kontak langsung, kontak tidak langsung, dan kontak droplet. Untuk mencegah penyebaran virus, CDC merekomendasikan untuk mencuci tangan dengan sabun dan air selama 20 detik, atau jika sabun dan air tidak tersedia, masyarakat dapat menggunakan pembersih tangan dengan alkohol minimal 60\% (Centers for Disease Control and Prevention 2020). Cuci tangan dengan 6 langkah yang direkomendasikan WHO untuk mencuci tangan secara menyeluruh dan teratur dengan sabun di bawah air mengalir karena dapat membunuh virus yang mungkin ada di tangan Anda, salah satunya yaitu Covid-19 (Kemenkes Republik Indonesia 2020).

Tangan kita adalah pembawa penting untuk penyebaran mikroorganisme. Transmisi silang ke orang lain dapat terjadi ketika kita gagal untuk mencuci tangan dengan baik dan benar.(Edmonds-Wilson et al. 2015). Mencuci tangan pakai sabun merupakan salah satu upaya sanitasi, tangan dan jari manusia dibersihkan dengan air dan sabun agar tetap bersih dan memutus rantai penyakit (Dinkes Bali 2020). Kepatuhan terhadap rekomendasi kebersihan tangan sangat penting dalam mencegah penyebaran COVID-19 dan, dalam keadaan apa pun, tidak boleh dikurangi dengan perubahan eksim yang dapat terjadi di tangan(Beiu et al. 2020). Kebersihan tangan adalah prinsip yang diterima secara luas dalam pencegahan penularan penyakit karena kebersihan tangan yang baik memiliki kemungkinan 24\% hingga 31\% untuk mengurangi penyebaran dari penyakit menular (Huang, Stewardson, and Grayson 2014; Kantor 2020).

Bukti dari literatur menunjukkan bahwa sering mencuci tangan akan mengurangi risiko penularan virus sebesar $55 \%$ (Jefferson et al. 2009; Luby et al. 2005). Selama wabah parah sindrom pernafasan akut (SARS), mencuci tangan dan memakai 
masker terbukti efektif dalam memblokir penyebaran virus (Jefferson et al. 2009). Mengajarkan praktik kebersihan tangan yang baik di dalammasyarakat telah terbukti menurunkan insiden diare sebesar 23-40\% dan infeksi saluran pernapasan sekitar 21\%(Aiello et al. 2008; Freeman et al. 2014) Di masa pandemi COVID-19 saat ini, edukasi dan informasi tentang cuci tangan difokuskan kepada para pekerja termasuk sektor kesehatan dan masyarakat umum.. Literatur telah mengungkapkan bahwa pengetahuan yang buruk tentang sehat praktik kebersihan tangan juga merupakan factor penting yang berkontribusi dalam peningkatan penyakit menular di negara berkembang(Sibiya and Gumbo 2013; Vivas et al. 2010)

Di Desa Lamsiteh Cot, diketahui bahwa mayoritas masyarakat masih belum mempunyai pengetahuan sepenuhnya mengenai Pentingnya cuci tangan pakai sabun, cara cuci tangan yang benar dan kapan harus cuci tangan pakai sabun. Dan kurangnya kesadaran masyarakat untuk menerapkan kebiasaan cuci tangan pakai sabun terutama di masa pandemi Covid-19. Salah satu upaya untuk membantu pemerintah dan meningkatkan kesehatan masyarakat dengan menekan penyebaran virus Covid-19 adalah dengan melaksanakan kegiatan pendidikan kesehatan dan sosialisasi cuci tangan yang baik dan benar. Diharapkan melalui kegiatan edukasi dan sosialisasi cuci tangan yang baik dan benar ini, masyarakat di Desa Lamsiteh Cot, semakin banyak masyarakat yang memahami manfaat dan pentingnya menggunakan sabun di air mengalir untuk mencuci tangan dengan benar, serta mau dan mampu mengembangkan kebiasaan tersebut. mencuci tangan mereka. Kekhawatiran. Wabah virus Covid-19.

\section{Metode}

Rencana kegiatan ini disusun oleh tim pelaksana kegiatan dan kerjasama dengan Kepala Desa Lamsiteh Cot. Tujuan Pengabdian masyarakat ini adalah untuk mengetahui dan memahami cara mencuci tangan dengan baik dan dapat melakukan teknik mencuci tangan dengan benar sebagai upaya untuk perubahan perilaku sehingga nantinya dapat meningkatkan derajat kesehatan masyarakat.

Sebelum kegiatan dilaksanakan, tim bersama dengan mahasiswa menemui Kepala Desa Lamsiteh Cot untuk menjalin kerjasama dalam pelaksanaan kegiatan pengabdian nantinya. Pada saat itu juga disepakati kegiatan apa saja yang akan dilaksanakan. Berdasarkan kontrak dengan Kepala Desa Lamsiteh Cot, kegiatan akan dilaksanakan pada hari Kamis, Persiapan yang akan dilakukan oleh tim pelaksana yaitu materi, alat dan bahan yang akan digunakan serta konsumsi untuk peserta kegiatan. Sasaran dalam kegiatan ini adalah Masyarakat Desa Lamsiteh Cot. Adapun tahapan kegiatan yang akan dilakukan adalah pembukaan oleh moderator, selanjutnya penyampaian sambutan dari Kepala Desa Lamsiteh Cot. Kemudian dilanjutkan pemaparan materi oleh Tim Pengabdian. Setelah pemberian materi oleh pemateri, selanjutnya tim pengabdi membagikan leaflet serta menjelaskan tentang cuci tangan yang baik dan benar apalagi dimasa pandemic saat ini. Setelah kegiatan dilakukan diharapkan masyarakat mengetahui dan memahami cara mencuci tangan dengan baik dan dapat melakukan teknik mencuci tangan dengan benar sebagai upaya untuk perubahan perilaku sehingga nantinya dapat meningkatkan derajat kesehatan masyarakat

\section{Hasil dan Pembahasan}

Kegiatan dilaksanakan pada hari Kamis, Tanggal 18 Februari di Desa Lamsiteh Cot. Peserta penyuluhan sebanyak 13 warga. Penyuluhan dilakukan dengan metode diskusi disertai dengan tanya jawab serta dengan mempraktikkan langsung cuci tangan yang baik dan benar. Media yang digunakan dalam kegiatan ini menggunakan leaflet dan dilanjutkan dengan mempraktikkan langsung cuci tangan yang baik dan benar di air mengalir dan menggunakan sabun. 


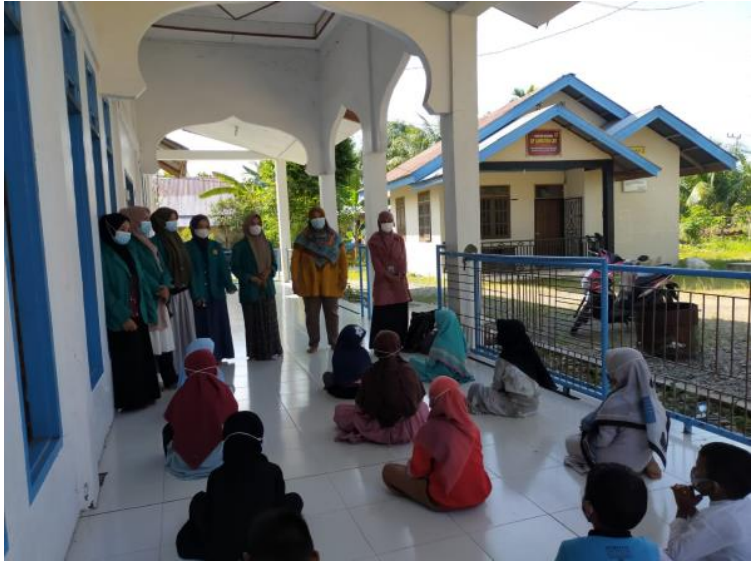

Gambar 1. Pemberian edukasi cuci tangan yang baik dan benar dalam rangka pencegahan Covid-19

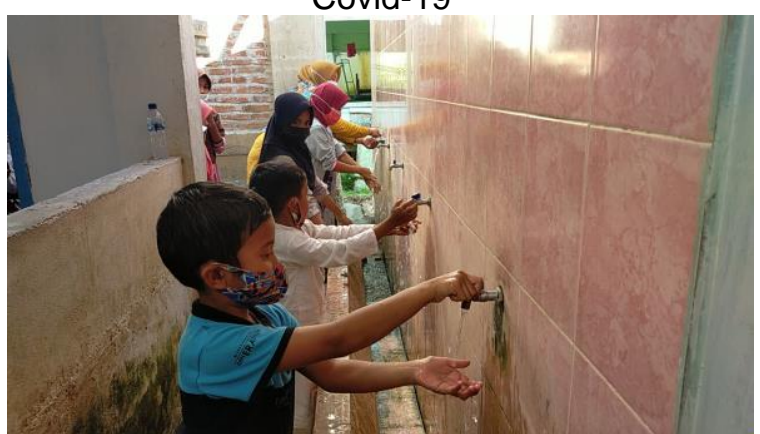

Gambar 2. Praktik cuci tangan yang baik dan benar dalam rangka pencegahan Covid-19

Masyarakat Di Desa Lamsiteh Cot mengatakan sangat senang mendapatkan Edukasi dan sosialisasi cuci tangan yang benar dan benar untuk meningkatkan pengetahuan dan meningkatkan perilaku hidup bersih dan sehat Ini membantu mencegah penyebaran pandemi COVID-19. Kegiatan ini mendapatkan respon yang antusias dan kooperatif dari masyarakat. Dengan adanya Edukasi dan Sosialosasi Cuci Tangan yang baik dan benar terbukti dapat menambah pengetahuan masyarakat tentang pentingnya Pentingnya cuci tangan yang baik dan benar dalam rangka untuk mencegah Penyebaran Covid-19. Pentingnya cuci tangan tidak dapat diabaikan karena mereka rentan terhadap infeksi yang disebabkan oleh tangan yang tidak bersih

Mencuci tangan merupakan salah satu upaya kesehatan masyarakat yang vital. Mencuci tangan dengan benar sesering mungkin (minimal 40 detik) adalah salah satu langkah terpenting untuk mencegah infeksi Covid-19. Mencuci tangan dengan sabun lebih efektif membunuh bakteri dan virus daripada mencuci tangan dengan air saja. Sabun dengan mudah menghancurkan membran lipid Covid-19 dan mematikan virus Covid-19 (Kemenkes Republik Indonesia 2020).

Hand Hygiene adalah tindakan yang efektif dalam mencegah penularan penyakit coronavirus 2019 (COVID-19). WHO dan CDC dan telah merekomendasikan cuci tangan- dengan sabun dan air setelah batuk/bersin, mengunjungi tempat umum, menyentuh permukaan di luar rumah, dan merawat orang yang sakit, serta sebelum dan sesudah makan. Ketika sabun dan air tidak tersedia, pembersih tangan berbasis alcohol dapat digunakan (CDC 2021; WHO 2020a). Sering mencuci tangan telah menjadi hal yang lumrah sehingga memicu seruan untuk menegur orang untuk terlibat dalam mencuci tangan rasional yang menyeimbangkan kebersihan yang memadai dengan kebutuhan untuk menjaga perawatan kulit (Cavanagh and Wambier 2020)

Pembinaan telah dilakukan dengan cukup baik. Materi yang diberikan disertai dengan demonstrasi cara mencuci tangan yang benar dan benar. Mencuci tangan dengan air saja tidak cukup untuk membunuh bakteri penyebab penyakit. Mencuci tangan dengan sabun dan air bersih merupakan cara yang efektif untuk melindungi kita dari penyakit menular termasuk Covid-19. Fakta membuktikan bahwa mencuci tangan dengan sabun setidaknya selama 40-60 detik dan mengikuti semua langkah yang direkomendasikan dapat membunuh bakteri secara efektif. Jika fasilitas cuci tangan pakai sabun tersedia, dilakukan pada saatsaat penting, dan dengan cara yang benar, cuci tangan pakai sabun bisa efektif. Mencuci tangan dengan sabun, penting dalam perang melawan virus corona. Mencuci tangan dengan sabun, jika dilakukan dengan benar, sangat penting dalam memerangi penyakit virus corona baru (COVID-19), tetapi jutaan orang tidak memiliki akses yang siap untuk tempat untuk mencuci tangan. Mencuci tangan dengan sabun adalah salah satu hal termurah dan paling efektif yang dapat Anda lakukan untuk melindungi diri sendiri dan orang lain dari virus corona, serta banyak penyakit menular lainnya. Mencuci tangan juga menjadi kunci untuk melindungi 
petugas kesehatan dari infeksi dan mencegah penyebaran COVID-19 dan infeksi lain di fasilitas kesehatan(UNICEF 2020).

Mencuci tangan dapat mencegah sekitar $30 \%$ penyakit terkait diare dan sekitar $20 \%$ infeksi pernapasan (misalnya, pilek) (Ejemot et al. 2008; Rabie and Curtis 2006). Mencuci tangan dengan cara yang benar dapat mengurangi tingkat diare dengan $40 \%$, infeksi saluran pernafasan sebesar $23 \%$ dan juga mencegah terjadinya berbagai wabah penyakit menular penyakit yang menyebar melalui tangan yang terkontaminasi.

\section{Kesimpulan}

Kegiatan Edukasi dan Sosialosasi Pencegahan Penyebaran Covid-19 dengan Cuci Tangan yang baik dan benar mendapat sambutan yang baik dari peserta. Masyarakat mengatakan sangat senang mendapatkan informasi tentang PHBS untuk menambah pengetahua dan menerapkan perilaku cuci tangan yang baik dan benar Kegiatan pengabdian kepada masyarakat mengenai pendidikan kesehatan (penyuluhan) tentang Edukasi dan Sosialosasi Pencegahan Penyebaran Covid-19 dengan Cuci Tangan yang baik dan benar mendapatkan respon yang antusias dan kooperatif dari para santri di dayah darul aman.

\section{Daftar Pustaka}

Aiello, Allison E., Rebecca M. Coulborn, Vanessa Perez, and Elaine L. Larson. 2008. "Effect of Hand Hygiene on Infectious Disease Risk in the Community Setting: A MetaAnalysis." American Journal of Public Health 98(8):1372-81.

Aiello, Allison E., Vanessa Perez, Rebecca M. Coulborn, Brian M. Davis, Monica Uddin, and Arnold S. Monto. 2012. "Facemasks, Hand Hygiene, and Influenza among Young Adults: A Randomized Intervention Trial." PloS One 7(1):e29744.

Aledort, Julia E., Nicole Lurie, Jeffrey Wasserman, and Samuel A. Bozzette. 2007.
Pharmaceutical Public Health Interventions for Pandemic Influenza: An Evaluation of the Evidence Base." BMC Public Health 7(1):208.

Badan Informasi Geospasial. 2021. "The United Kingdom: WHO Coronavirus Disease (COVID-19) Dashboard With Vaccination Data | WHO Coronavirus (COVID-19) Dashboard With Vaccination Data." Retrieved (https://covid19.who.int/region/euro/ country/gb).

Beiu, Cristina, Mara Mihai, Liliana Popa, Luiza Cima, and Marius N. Popescu. 2020. "Frequent Hand Washing for COVID-19 Prevention Can Cause Hand Dermatitis: Management Tips." Cureus 12(4).

Cavanagh, Gregory, and Carlos Gustavo Wambier. 2020. "Rational Hand Hygiene during the Coronavirus 2019 (COVID-19) Pandemic." Journal of the American Academy of Dermatology 82(6):e211.

CDC. 2021. "How to Protect Yourself and Others Know How It Spreads." Cdc 2019:18-19.

Centers for Disease Control and Prevention. 2020. "Show Me the Science - How to Wash Your Hands | Handwashing | CDC."

Dinkes Bali. 2020. "Ayo Kita Lakukan Cuci Tangan Pakai Sabun (CTPS) Sebagai Salah Satu Upaya Pencegahan Covid19 - Dinas Kesehatan Provinsi Bali." Dinas Kesehatan Pemerintah Provinsi Bali.

Edmonds-Wilson, Sarah L., Nilufar I. Nurinova, Carrie A. Zapka, Noah Fierer, and Michael Wilson. 2015. "Review of Human Hand Microbiome Research." Journal of Dermatological Science 80(1):3-12.

Ejemot, R. I., J. E. Ehiri, M. M. Meremikwu, and J. A. Critchley. 2008. "Hand Washing for Preventing Diarrhoea." The Cochrane Database of Systematic Reviews (1):CD004265.

Freeman, Matthew C., Meredith E. Stocks, Oliver Cumming, Aurelie Jeandron, Julian P. T. Higgins, Jennyfer Wolf, Annette Prüss-Ustün, Sophie Bonjour, Paul R. Hunter, Lorna 
Fewtrell, and Valerie Curtis. 2014. "Hygiene and Health: Systematic Review of Handwashing Practices Worldwide and Update of Health Effects." Tropical Medicine \& International Health: TM \& $\mathrm{IH}$ 19(8):906-16.

Huang, Gene K. L., Andrew J. Stewardson, and Michael L. Grayson. 2014. "Back to Basics: Hand Hygiene and Isolation." Current Opinion in Infectious Diseases 27(4):379-89.

Jefferson, Tom, Chris Del Mar, Liz Dooley, Eliana Ferroni, Lubna A. Al-Ansary, Ghada A. Bawazeer, Mieke L. van Driel, Ruth Foxlee, and Alessandro Rivetti. 2009. "Physical Interventions to Interrupt or Reduce the Spread of Respiratory Viruses: Systematic Review." BMJ 339.

Kantor, Jonathan. 2020. "Behavioral Considerations and Impact on Personal Protective Equipment Use: Early Lessons from the Coronavirus (COVID-19) Pandemic." Journal of the American Academy of Dermatology 82(5):1087-88.

Kemenkes Republik Indonesia. 2020. "Panduan Cuci Tangan Pakai Sabun." Kesehatan Lingkungan 20.

Luby, Stephen P., Mubina Agboatwalla, Daniel R. Feikin, John Painter, Ward Billhimer, Arshad Altaf, and Robert M. Hoekstra. 2005. "Effect of Handwashing on Child Health: A Randomised Controlled Trial." Lancet (London, England) 366(9481):225-33.

Rabie, Tamer, and Valerie Curtis. 2006. "Handwashing and Risk of Respiratory Infections: A Quantitative Systematic Review." Tropical Medicine \& International Health: TM \& IH 11(3):258-67.

Remuzzi, Andrea, and Giuseppe Remuzzi. 2020. "COVID-19 and Italy: What Next?" Lancet (London, England) 395(10231):1225-28.

Satgas Penanganan COVID-19. 2020. "Analisis Data COVID-19 Indonesia Update Per 03 Januari 2021." Satuan Gugus Tugas Penanganan COVID-19 Indonesia (January):1174.
Sibiya, Jerry E., and Jabulani Ray Gumbo. 2013. "Knowledge, Attitude and Practices (KAP) Survey on Water, Sanitation and Hygiene in Selected Schools in Vhembe District, Limpopo, South Africa." International Journal of Environmental Research and Public Health 10(6):2282-95.

UNICEF. 2020. "FACT SHEET : Handwashing with Soap, Critical in the Fight against Coronavirus, Is 'out of Reach' for Billions." United Nations Children's Fund 95(14):45109.

Vivas, A. P., B. Gelaye, N. Aboset, A. Kumie, Y. Berhane, and M. A. Williams. 2010. "Knowledge, Attitudes and Practices (KAP) of Hygiene among School Children in Angolela, Ethiopia." Journal of Preventive Medicine and Hygiene 51(2):73-79.

WHO. 2020a. "Advice for the Public."

WHO. 2020b. "Novel Coronavirus." Situation Report - 205 205(6):1-19. 